\title{
Методи ітеративного декодування кодів 3 малою щільністю перевірок на парність
}

Наведено способи формального подання кодів з малою щиільністю перевірок на парність, які визначають особливості класичних методів ітеративного декодування даних кодів. Показано, щчо класичні методи ітеративного декодування кодів з малою щзільістю перевірок на парність мають ряд обмежень з точки зору обчислювальної складності та ефективності декодування. Визначено особливості класичних методів ітеративного декодування кодів з малою щільністю перевірок на парність та обтрунтовано можливість їх застосування у комбінованому методі декодування даних кодів.

Ключові слова: декодування, коди, ітеративні, комбінований.

\begin{abstract}
Постановка проблеми та аналіз літератури
Розвиток телекомунікацій базується на побудові телекомунікаційних систем на основі новітніх технологій, стандартів та протоколів. Важливим завданням при створенні телекомунікаційних систем $\epsilon$ забезпечення заданої достовірності передачі інформації, що визначається конкретним додатком. Значна кількість сучасних телекомунікаційних технологій і стандартів використовує для даної мети коди 3 малою щільністю перевірок на парність спільно 3 різноманітними методами ітеративного декодування, що дозволяють отримати жорстке або м'яке рішення [1 - 4]. При цьому дані методи декодування мають ряд обмежень, що призводить до необхідності підвищення ефективності декодування кодів 3 малою щільністю перевірок на парність для забезпечення заданої достовірності передачі інформації у телекомунікаційних системах шляхом розробки комбінованих методів декодування [5].

Таким чином, актуальною задачею $є$ визначення особливостей класичних методів ітеративного декодування кодів 3 малою щільністю перевірок на парність, які необхідно враховувати при їх застосуванні у комбінованих методах декодування даних кодів.
\end{abstract}

\section{Мета статті \\ Визначення особливостей класичних методів ітеративного декодування кодів 3 малою щільністю перевірок на парність та обгрунтування можливості їх застосування у комбінованих методах декодування даних кодів.}

Основна частина
Коди 3 малою щільністю перевірок на парність
(МЩПП-коди) - це лінійні блокові коди, що задаються розрідженою перевірочною матрицею $H$, яка складається із малої кількості ненульових елементів [1].

Перевірочна матриця $H$ двійкового МЩПП-коду $C$ довжиною $n$ з $k$ інформаційними символами та $m=n-k$ перевірочними символами, тобто $(n, k)$ МЩПП-коду, має вигляд

$H=\left(\begin{array}{llll}h_{11} & h_{12} & \ldots & h_{1 n} \\ h_{21} & h_{22} & \ldots & h_{2 n} \\ \mathrm{M} & \mathrm{M} & h_{i j} & \mathrm{M} \\ h_{m 1} & h_{m 2} & \ldots & h_{m n}\end{array}\right)$,

де $h_{i j}-i j$-й елемент матриці, $h_{i j} \in\{0,1\}$, $i \in[1, m], j \in[1, n]$.

Тоді будь-яке кодове слово $\bar{c}$ даного коду задовольняє умову

$H \bar{c}=0$,

a для деякого двійкового прийнятого вектора $\bar{d}$ можна визначити синдром за формулою

$\bar{s}=H \bar{d}$

3 (1) та (3) випливає, що $i$-та складова синдрому (перевірочна умова) прийнятого вектора дорівнює

$s_{i}=\sum_{j=1}^{n} d_{j} h_{i j}, i \in[1, m]$, 
де $d_{j}-j$-й елемент двійкового прийнятого вектора.

Таким чином, з урахуванням (1) - (4) двійковий МщПП-код $C$ формально можна подати таким чином:

$C \equiv\left\{c_{j} \in\{0,1\}: s_{i}=\sum_{j=1}^{n} c_{j} h_{i j}=0, i \in[1, m], j \in[1, n]\right\}$,

де $c_{j}-j$-й елемент кодового слова.

Також МЩПП-коди можна подати за допомогою графів Таннера, вершини яких поділяються на дві групи, що з'єднані між собою ребрами. Перша група складається $3 n$ бітових вершин $V_{j}$, а друга $-3 m$ перевірочних вершин $P_{i}$. Перевірочна вершина $P_{i}$ з'єднується 3 бітовою вершиною $V_{j}$, якщо елемент перевірочної матриці (1) дорівнює $1\left(h_{i j}=1\right)$, у противному випадку - ребро між даними вершинами відсутнє. Таким чином, перевірочна матриця (1) деякого МЩПП-коду може розглядатися як матриця інцидентності графу Таннера.

Множина $N(i) \equiv\left\{j \in[1, n]: h_{i j}=1\right\} \quad$ включає бітові вершини, що пов'язані $3 i$-ю перевірочною вершиною, тобто визначає елементи прийнятого вектора, які входять до $i$-ї перевірочної умови.

Множина $M(j) \equiv\left\{i \in[1, m]: h_{i j}=1\right\}$ включає перевірочні вузли, які пов'язані $3 j$-ю бітовою вершиною, тобто визначає перевірочні умови, у яких задіяно $j$-й елемент прийнятого вектора $[1,2]$.

Граф Таннера $(n, k)$ МЩПП-коду з наведеними вище позначеннями подано на рисунку.

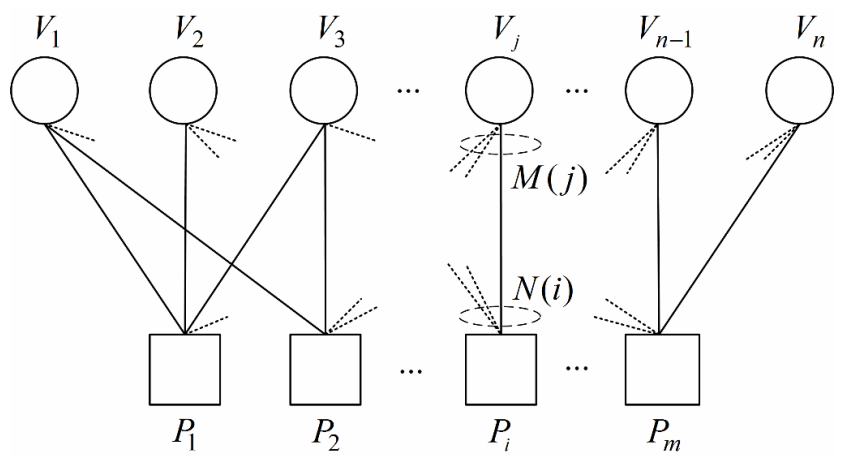

Рис. Граф Таннера $(n, k)$ МЩПП-коду

Класичні методи ітеративного декодування МЩПП-кодів засновані на послідовному уточненні кожного елементу передбачуваного кодового слова та перевірці умови (2), що еквівалентно ітеративному обміну повідомленнями між бітовими та перевірочними вершинами графу Таннера. До класичних методів ітеративного декодування МЩППкодів відносяться метод жорсткого декодування на основі інвертування біта та метод м'якого декодування на основі розповсюдження довіри [1]. Дані методи забезпечують різну достовірність передачі інформації, що оцінюється ймовірністю помилки декодування, та відрізняються обчислювальною складністю, що визначається необхідною кількістю ітерацій, типом та кількістю операцій тощо.

Метод жорсткого декодування МЩПП-кодів на основі інвертування біта подано наступними етапами.

Етап 1. Обчислення кожної перевірочної умови $S_{i}$ для прийнятого вектора $\bar{d}$ за формулою (4).

Етап 2. Визначення числа невиконаних перевірочних умов для $j$-го елементу прийнятого вектора.

Етап 3. Формування передбачуваного кодового слова $\bar{c}^{\prime}$ шляхом інвертування елементу $d_{j}{ }^{3}$ найбільшим числом невиконаних перевірочних умов.

Етап 4. Перевірка умови закінчення декодування. Якщо для передбачуваного кодового слова $\bar{c}^{\prime}$ виконується умова (2) або досягнуто максимальне число ітерацій, то процес декодування завершується, в іншому випадку - перехід до етапу 1.

3 аналізу етапів даного методу декодування випливає його низька обчислювальна складність через необхідність виконання лише двійкових операцій, що обумовлює доцільність його використання у додатках 3 високою швидкістю передачі. При цьому даний метод характеризується відносно високою ймовірністю помилки декодування, що знижує достовірність передачі інформації у телекомунікаційних системах.

Основні етапи методу м'якого декодування МЩПП-кодів на основі розповсюдження довіри наведено нижче.

Етап 1. Ініціалізація.

Встановлення для бітової вершини $V_{j}$, що з'єднана ребром з перевірочною вершиною $P_{i}$, таких значень ймовірностей:

$$
p_{j}^{1}=\frac{1}{1+e^{\frac{2 y_{j}}{\sigma^{2}}}}, \quad p_{j}^{0}=1-p_{j}^{1}
$$

$$
P_{i j}^{1}=p_{j}^{1}, \quad P_{i j}^{0}=1-P_{i j}^{1}
$$


де $p_{j}^{1}, p_{j}^{0}$ - ймовірності того, що $j$-й елемент прийнятого вектора $d_{j}=1$ або $d_{j}=0$ відповідно;

$y_{j}-j$-й елемент прийнятого вектора м'яких рішень;

$\sigma^{2}$ - дисперсія каналу 3 адитивним білим гаусовим шумом;

$P_{i j}^{1}, \quad P_{i j}^{0}$ - ймовірності того, що $j$-й елемент прийнятого вектора $d_{j}=1$ або $d_{j}=0$, які визначаються на основі інформації, отриманої з усіх перевірочних умов, окрім умови $S_{i}$, відповідно.

Етап 2. Передача повідомлень від перевірочних вершин до бітових вершин.

Обчислення для кожної перевірочної вершини $P_{i}$, що пов'язана ребром з бітовою вершиною $V_{j}$, різниці між значеннями ймовірностей (7) та допоміжної величини:

$$
\begin{aligned}
& \Delta P_{i j}=P_{i j}^{0}-P_{i j}^{1} . \\
& \Delta Q_{i j}=\prod_{j^{\prime}} \Delta P_{i j^{\prime}},
\end{aligned}
$$

де $j^{\prime} \in N(i) \backslash\{n\}$.

Визначення ймовірності того, що перевірочна умова $s_{i}$ виконується, якщо $j$-й елемент прийнятого вектора $d_{j}=1$ або $d_{j}=0$ відповідно:

$Q_{i j}^{1}=\frac{1}{2}\left(1-\Delta Q_{i j}\right), \quad Q_{i j}^{0}=\frac{1}{2}\left(1+\Delta Q_{i j}\right)$

Етап 3. Передача повідомлень від бітових вершин до перевірочних вершин.

Обчислення ймовірностей (7) для кожної бітової вершини $V_{j}$, що з’єднана ребром 3 перевірочною вершиною $P_{i}, \quad 3$ урахуванням умови нормування $P_{i j}^{0}+P_{i j}^{1}=1$ :

$P_{i j}^{1}=p_{j}^{1} \prod_{i^{\prime}} Q_{i^{\prime} j}^{1}, \quad P_{i j}^{0}=p_{j}^{0} \prod_{i^{\prime}} Q_{i^{\prime} j}^{0}$,

де $i^{\prime} \in M(j) \backslash\{m\}$.

Визначення апостеріорних ймовірностей, що уточнюють значення ймовірностей (6), з урахуванням (8) та умови нормування $P_{j}^{0}+P_{j}^{1}=1$ :
$P_{j}^{1}=p_{j}^{1} \prod_{i} Q_{i j}^{1}, \quad P_{j}^{0}=p_{j}^{0} \prod_{i} Q_{i j}^{0}$

Етап 4. Перевірка умови закінчення декодування. Визначення значення $j$-го елементу передбачуваного кодового слова $\bar{c}^{\prime}$ на основі значень ймовірностей, що отримані за допомогою (9):

$c_{j}^{\prime}=\left\{\begin{array}{l}0, \text { при } \ln \left(P_{j}^{1} / P_{j}^{0}\right) \geq 0, \\ 1, \text { при } \ln \left(P_{j}^{1} / P_{j}^{0}\right)<0,\end{array}\right.$

де $\ln \left(P_{j}^{1} / P_{j}^{0}\right) \quad$ - логарифмічне відношення ймовірностей (м'які рішення).

Якщо для передбачуваного кодового слова $\bar{c}^{\prime}$ виконується умова (2) або досягнуто максимальне число ітерацій, то процес декодування завершується, в іншому випадку - перехід до етапу 2 [1].

3 аналізу етапів поданого методу декодування випливає, що його недоліком $\epsilon$ висока обчислювальна складність, яка обумовлена значною кількістю обчислень ймовірностей, що потребують операцій 3 дійсними числами. При цьому даний метод забезпечує низьку ймовірність помилки декодування, тому його доцільно застосовувати у додатках, які потребують високої достовірності передачі інформації.

\section{Висновки}

МЩПП-коди задаються розрідженою перевірочною матрицею або графом Таннера, які визначають особливості методів ітеративного декодування даних кодів, що засновані на послідовному уточненні кожного елементу передбачуваного кодового слова, що еквівалентно ітеративному обміну повідомленнями між бітовими та перевірочними вершинами графу Таннера.

Проведений аналіз показав, що класичні методи ітеративного декодування МЩПП-кодів мають ряд обмежень $з$ точки зору обчислювальної складності та ефективності декодування, тому виникає необхідність у розробці комбінованого методу декодування МЩПП-кодів 3 прийнятною обчислювальною складністю, що забезпечує задану достовірність передачі інформації у телекомунікаційних системах.

Одним із варіантів реалізації комбінованого методу декодування МЩПП-кодів $є$ спільне застосування класичного методу м'якого декодування на основі розповсюдження довіри та методу декодування на основі процедур природних обчислень [6]. 


\section{Література}

1. Штомпель, Н. А. Методы мягкого декодирования кодов с малой плотностью проверок на четность [Текст] / Н. А. Штомпель // Вісник Національного технічного університету «Харківський політехнічний інститут»: зб. наук. пр. - 2013. № 27 (1000). - C. 163 - 168 .

2. Wadayama, T. Gradient descent bit flipping algorithms for decoding LDPC codes / T. Wadayama, K. Nakamura, M. Yagita, Y. Funahashi, S. Usami, I. Takumi // IEEE Transactions on Communications. 2010. - Vol. 58, № 6. - June. - P. 1610 - 1614.

3. Асауленко, І. О. Метод декодування кодів з малою щільністю перевірок на парність на основі стохастичної оптимізації [Текст] / I. О. Асауленко, С. І. Приходько, М. А. Штомпель // Інформаційнокеруючі системи на залізничному транспорті: науково-технічний журнал. - Харків: УкрдУЗТ, 2015. - Вип. 5 (114). - С. 61 - 65.

4. Асауленко, I. О. Дослідження характеристик методу декодування кодів 3 малою щільністю перевірок на парність на основі стохастичної оптимізації [Текст] / I. О. Асауленко, О.С. Жученко, С. І. Приходько, М. А. Штомпель // Інформаційно-керуючі системи на залізничному транспорті: науково-технічний журнал. Харків: УкрдУЗТ, 2016. - Вип. 1 (116). - С. 33 40.

5. Штомпель, Н. А. Комбинированный метод декодирования кодов с малой плотностью проверок на четность [Текст] / Н. А. Штомпель // Науково-практична конференція «Застосування інформаційних технологій у підготовці та діяльності сил охорони правопорядку» (м. Харків, 12 - 13 березня 2014 р.). - Збірник тез доповідей. Харків: Академія внутрішніх військ МВС України, 2014. - С. $96-97$.

6. Жученко, А. С. Метод декодирования блоковых кодов на основе процедур природных вычислений [Текст] / А. С. Жученко, Н. А. Штомпель // II Міжнародна науково-технічна конференція «Актуальні проблеми розвитку науки і техніки» (м. Київ, 20 грудня 2015 р.). - Збірник тез. - К.: ДУТ, 2015. - С. 7.

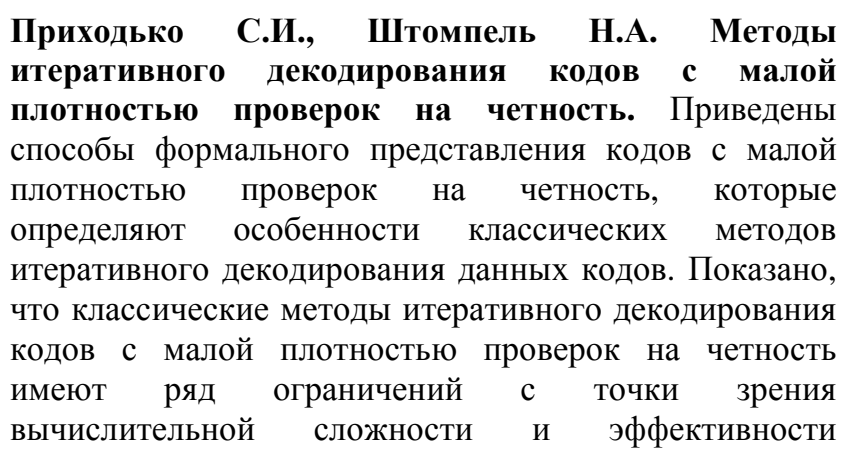

декодирования. Определены особенности классических методов итеративного декодирования кодов с малой плотностью проверок на четность и обоснована возможность их применения в комбинированном методе декодирования данных кодов.

Ключевые слова: декодирование, коды, итеративные, комбинированный.

Prihodko S., Shtompel M. Iterative decoding methods of low density parity check codes. The development of telecommunications is based on the construction of telecommunications systems based on the latest technologies, standards and protocols. The important task in creating telecommunication systems is to ensure the reliability of giving transmission of information which determined by the specific application. Significant number of modern telecommunication technologies and standards were used for this purpose low density parity check codes in conjunction with the various methods of iterative decoding which allowing to obtain hard or soft decisions. There are ways of formal representations of low density parity check codes which define features of classical methods iterative decoding data codes. It shows the classical iterative decoding methods low density parity check codes have limitations in terms of computational complexity and decoding efficiency. The features of the classical methods of iterative decoding of low density parity check codes and demonstrated the possibility of their use in a combined decoding method of this codes.

Keywords: decoding, codes, iterative, combined.

Рецензент д.т.н., професор Альошин Г.В. (УкрдУЗТ)

Надійшла 06.06.2016 p.

Приходько Сергій Іванович, доктор технічних наук, професор, проректор з науково-педагогічної роботи, Український держсвний університет залізничного транспорту, Харків, Україна. E-mail: tz@kart.edu.иа.

Штомпель Микола Анатолійович, кандидат технічних наук, дочент, доиент кафедри транспортного зв'язку, Украӥнський державний університет залізничного транспорту, Харків, Україна. E-mail: tz@kart.edu.иа.

Prihodko S.I., Vice-rector for scientific and pedagogical work of Ukrainian State University of Railway Transport, Doctor of Technical Sciences, professor, Ukrainian State University of Railway Transport, Kharkiv, Ukraine. E-mail: tz@kart.edu.ua.

Shtompel M.A., docent of "Transport connection" department, Candidate of Techn. Sciences, docent, Ukrainian State University of Railway Transport, Kharkiv, Ukraine. E-mail:tz@kart.edu.ua. 